\title{
Measurement of radium isotope activities in reservoir and spring water in the Cameroon Central Region
}

\author{
Rose Lydie Marie', Oum Keltoum Hakam², Abdelmajid Choukri² \\ ${ }^{I}$ Department of Radiation Emergencies, National Radiation Protection Agency, Yaoundé, Cameroon \\ ${ }^{2}$ Department of Physics, University Ibn Tofail, Kenitra, Morocco
}

[Presented at the $4^{\text {th }}$ African Regional IRPA congress (AFRIRPA04), which was held from September 13-17, 2014 in Rabat, Morocco. This paper was reviewed and accepted by the scientific committee of the $4^{\text {th }}$ African Regional IRPA congress]

\section{Conference Proceeding}

\begin{abstract}
Purpose: To determine the activities of ${ }^{226} \mathrm{Ra}$ and ${ }^{228} \mathrm{Ra}$ in the reservoir and spring water samples respectively during the dry and the rainy seasons; and to calculate the annual intake Ii (Bq/y) for each type of water samples. Methods: Using both well calibrated Canberra $\mathrm{NaI}(\mathrm{Tl})$ and $\mathrm{HPGe}$ detector systems, it was possible to determine the average specific activity of those radium's isotopes in water samples which were collected in 2010, from Reservoirs and springs in Cameroon central region including Ngoaekelle, Minboman, Etoudi and Njoungolo. Results: The average specific activity values obtained for ${ }^{226} \mathrm{Ra}$ and ${ }^{228} \mathrm{Ra}$ in reservoir water samples were $8.76 \pm 3.50 \mathrm{BqL}^{-1}$ and $0.64 \pm 0.28 \mathrm{BqL}^{-1}$ during the dry season and, $8.24 \pm 3.48 \mathrm{BqL}^{-1}$ and $0.58 \pm 0.24$ $\mathrm{BqL}^{-1}$ during the rainy season respectively. For spring water, the average values were $3.50 \pm 0.63 \mathrm{BqL}^{-1}$ and below $0.0002 \mathrm{BqL}^{-1}$ (detection limit of ${ }^{228} \mathrm{Ra}$ in water) during the dry season; $3.20 \pm 0.60 \mathrm{BqL}^{-1}$ and below $0.0002 \mathrm{BqL}^{-1}$ (detection limit of ${ }^{228} \mathrm{Ra}$ in water) during the rainy season respectively. Assuming that the volume of drinking water for adult is 2.5 litres per day, the average annual intakes of ${ }^{226} \mathrm{Ra}$ and ${ }^{228} \mathrm{Ra}$ through ingestion in these water samples were $7702 \mathrm{~Bq} / \mathrm{y}$ and $575 \mathrm{~Bq} / \mathrm{y}$ for reservoir water; $2993 \mathrm{~Bq} / \mathrm{y}$ and $<0.25$ for spring water respectively. Conclusion: The results have indicated that the annual intake by the population of sampling region as a result of ${ }^{226} \mathrm{Ra}$ in these drinking waters is $7.7 \times 10^{3} \mathrm{~Bq} / \mathrm{y}$ more than the maximum limit fixed by ICRP which is $7 \times 10^{3} \mathrm{~Bq} / \mathrm{y}$. There is a need for regular monitoring the radiological water quality aspect in this region.
\end{abstract}

Keywords: Water; Natural Radionuclide; Concentration; Gamma Spectrometry

\section{Introduction}

There are different forms of uranium but ${ }^{238} \mathrm{U}$ is the predominant contributor to natural radioactivity. ${ }^{1}$ Enhance level of uranium, thorium and their fission products might be present in water in areas that are rich in natural radioactivity. Several radionuclides coming from the radioactive decay chain starting from ${ }^{238} \mathrm{U}$ and ${ }^{235} \mathrm{U}$ are highly radiotoxic. The most radiotoxic and most important among them is radium, which is a known carcinogen and exists in several isotopic forms. The predominant radium isotopes in ground water is ${ }^{226} \mathrm{Ra}$, an alpha emitter with a half-life of 1600 years, and ${ }^{228} \mathrm{Ra}$, a beta emitter with a half-life of $5.8 y e a r .^{2}$ When radium is taken into the body; its metabolic behaviour is similar to that of calcium and an appreciable fraction being distributed almost uniformly in soft tissues. ${ }^{3}$

\section{Methods and Materials}

The study was conducted on 88 samples water coming from reservoirs and springs. The major bedrock types of sampling region include gneiss, pegmatite, pegmatite schist and undifferentiated schist. ${ }^{4}$ Reservoir and spring water studied are used for drinking, washing clothes, cleaning of food, for irrigation, and for various domestic uses. The water samples were collected with great care, so as to reduce turbulence and thus, reduce radon loss. ${ }^{5}$ After been collected as mentioned above, the water samples were transferred to 1 litre kegs prior to processing for $\gamma$-spectrometry analysis.

All the water samples were acidified with $11 \mathrm{M}$ of $\left(\mathrm{H}_{3} \mathrm{O}^{+}, \mathrm{Cl}-\right)$ at the rate of $10 \mathrm{ml}$ per litre of sample as soon as possible after sampling to avoid absorption of radionuclides on to the walls of the containers as documented by the International Atomic Energy Agency. ${ }^{6}$ Marinelli beakers of 1 litre volume capacity previously washed, rinsed with a dilute sulphuric acid and dried to avoid contamination were filled with known volume of the various water samples and later firmly sealed for, at least, four weeks to ensure that no loss of radon occurs thereby assume a state of secular equilibrium to be reached between radium isotopes and their respective daughters. From each location, four samples were made from water collected. 
The first Gamma-counting equipment was a Canberra sodium iodide thallium activated $\mathrm{NaI}(\mathrm{Tl})$ crystal detector model GC2018-7500, serial number b 87063. This crystal used has an excellent energy resolution; with a typical measurement time was 36000 seconds. The second Gamma counting system was a Canberra High Purity Germanium (HPGe) detector, model Gx3019-7500SL, serial number 11026235; with a counting time of 86400 seconds. Because of the cosmic radiation that continuously bombards the earth's atmosphere and the existence of natural radioactivity in environment, radiation detectors records some background signal which varies with the size and type of the detector as well as the extent of shield. Hence the knowledge of the net peak area (without the background) under the full-energy peak that appears in its spectrum is important to apply the peak efficiency data for any detector. In gamma spectrometry, the pulse height scale must be calibrated in terms of absolute gamma-ray energy if various peaks in the spectrum are to be properly identified. Also, any measurement of absolute gamma-ray emission rates requires knowledge of the detector efficiency. Thus, the detector system has to be calibrated in terms of energy and absolute efficiency. The energy and efficiency calibrations were done using a well calibrated standard water source supplied by the International Atomic Energy Agency (IAEA), Vienna, Austria. The techniques used are well described elsewhere.

The activity concentrations of ${ }^{226} \mathrm{Ra}$ and ${ }^{228} \mathrm{Ra}$ were indirectly obtained from the $\gamma$-rays emitted by their progenies. ${ }^{226} \mathrm{Ra}$ concentration was determined by considering the 609.3 $\mathrm{keV}$-rays of ${ }^{214} \mathrm{Bi}$ and $583.0 \mathrm{keV} \gamma$-rays of ${ }^{208} \mathrm{Tl}$ was used to determine that of ${ }^{228} \mathrm{Ra}$. The gamma spectroscopy analysis with $\mathrm{NaI}(\mathrm{Tl})$ crystal was carried out by a sophisticated spectra-analysis program, SAMPO 90 which matched $\gamma$-energies at various energy levels to a library of possible isotopes. ${ }^{7}$ Another sophisticated spectra-analysis program named Genie 2000 was used for the HPGe detector. The activities of the radionuclides were calculated from the difference between net peak and net background areas, accumulation time, absolute peak efficiency, absolute $\gamma$-ray emission probability ( $\gamma$-ray intensity) and the sample volume. Triplicate analyses were conducted on all the water samples to check on the reproducibility of results and the stability of the counting system.

\section{Results}

The Annual limits of Incorporation (LAI) by ingestion recommended by the International Commission on Radiation Protection (ICRP) are $7 \times 10^{3} \mathrm{~Bq} / \mathrm{y}$ for ${ }^{226} \mathrm{Ra}$ and $9 \times 10^{3} \mathrm{~Bq} / \mathrm{y}$ for ${ }^{228} \mathrm{Ra}$ assuming an individual annual consumption of 900 litres of water (about $2.5 \mathrm{~L}$ per day). ${ }^{8}$ In central region of Cameroon, there exists two main seasons. The dry season, this covers 91 days and the rainy season which covers 274 days. Intakes of ${ }^{226} \mathrm{Ra}$ and ${ }^{228} \mathrm{Ra}$ through ingestion of reservoir and spring water samples were calculated assuming that, the volume of drinking water for adult is 2.5 litres per day. Table 1 shows the summary of ${ }^{226} \mathrm{Ra}$ and ${ }^{228} \mathrm{Ra}$ activity concentration and Table 2 presents the evaluation of the annual intake of ${ }^{226} \mathrm{Ra}$ and ${ }^{228} \mathrm{Ra}$ in studied water samples.

TABLE 1: Mean specific activity of ${ }^{226} \mathrm{Ra}$ and ${ }^{228} \mathrm{Ra}\left(\mathrm{BqL}^{-1}\right)$ in reservoir and springs water samples.

\begin{tabular}{l|l|lll|ll}
\hline \hline \multirow{2}{*}{\begin{tabular}{l} 
Number \\
\multirow{2}{*}{ of samples }
\end{tabular}} & \multicolumn{4}{|c}{ Radionuclides } \\
\cline { 3 - 6 } & & \multicolumn{3}{|c}{${ }^{226} \mathrm{Ra}$} & \multicolumn{2}{c}{${ }^{228} \mathrm{Ra}$} \\
\cline { 3 - 6 } & 24 & $6.05-11.09$ & $8.76 \pm 3.50$ & $0.33-0.89$ & $0.64 \pm 0.28$ \\
Reservoir water (dry season) & 24 & $5.69-10.28$ & $8.24 \pm 3.48$ & $0.47-0.69$ & $0.58 \quad \pm 0.24$ \\
Reservoir water (rainy season) & 20 & $2.66-5.82$ & $3.5 \pm 0.63$ & $<0.0002$ & $<0.0002$ \\
Spring water (dry season) & 20 & $1.70-5.20$ & $3.2 \pm 0.60$ & $<0.0002$ & $<0.0002$ \\
Spring water (rainy season) & & &
\end{tabular}

TABLE 2: Annual intake Ii (Bq/y) of ${ }^{226} \mathrm{Ra}$ and ${ }^{228} \mathrm{Ra}$ in reservoir and spring water samples.

\begin{tabular}{|c|c|c|c|c|c|c|c|c|}
\hline Radionuclides & \multicolumn{4}{|c|}{${ }^{226} \mathrm{Ra}$} & \multicolumn{4}{|c|}{${ }^{228} \mathrm{Ra}$} \\
\hline Water samples & \multicolumn{2}{|c|}{ Reservoir } & \multicolumn{2}{|c|}{ Spring } & \multicolumn{2}{|c|}{ Reservoir } & \multicolumn{2}{|c|}{ Spring } \\
\hline Season & Dry & Rainy & Dry & Rainy & Dry & Rainy & Dry & Rainy \\
\hline $\mathrm{Ii}_{\mathrm{i}}\left(\mathrm{BqL}^{-1}\right)$ & 8.8 & 8.3 & 3.5 & 3.2 & 0.7 & 0.6 & $<0.0002$ & $<0.0002$ \\
\hline $\mathrm{Ii}_{\mathrm{i}}(\mathrm{Bq} /$ day $)$ & 22.0 & 20.8 & 8.8 & 8.0 & 1.8 & 1.5 & $<0.0005$ & $<0.0005$ \\
\hline Ii (Bq/Season) & 2002 & 5700 & 801 & 2192 & 164 & 411 & $<0.05$ & $<0.2$ \\
\hline $\mathrm{Ii}(\mathrm{Bq} / \mathrm{y})$ & \multicolumn{2}{|c|}{7702} & \multicolumn{2}{|c|}{2993} & \multicolumn{2}{|c|}{575} & \multicolumn{2}{|c|}{$<0.25$} \\
\hline
\end{tabular}

\section{Discussion}

The mean concentration of ${ }^{226} \mathrm{Ra}$ agreed with a range of values obtained by many investigators namely McCurdy and Mellor in 1981: 0.08 - $36.4 \mathrm{BqL}^{-1}$ in imported bottled water, and Loomis in1987: $1.5-124 \mathrm{BqL}^{-1}$ in public water supplies in North Carolina. ${ }^{9}$ The ${ }^{228} \mathrm{Ra}$ concentrations recorded for this work fell within the wide range of values $0.05-4.6 \mathrm{BqL}^{-1}$ quoted for the USA's imported bottled water by McCurdy and Mellor. ${ }^{10}$ The concentration values are relatively low during the rainy season; this could be due to the dilution effects of rain water. ${ }^{228} \mathrm{Ra}$ activity is not too different to the 
result $620 \pm 10 \mathrm{mBqL}^{-1}$ obtained by Hakam et al. in 2001 in the drinking water from Fez locality in Morocco. ${ }^{8}$ While they are higher than $0.20-135 \mathrm{pCiL}^{-1}$ equivalent to 0.007 $0.05 \mathrm{BqL}^{-1}$, obtained by Ahmed in 2004 in tap water from Qena locality in Egypt. ${ }^{11}$ They are still within the range of $0.00-8.75 \mathrm{BqL}^{-1}$ reported by David et al. in 1981, quoted by McCurdy and Mellor for domestic bottled water marketed and consumed in USA. The specific activity due to natural thorium is relatively low in all the water samples investigated; this is because ${ }^{238} \mathrm{U}$ is more mobile than ${ }^{232} \mathrm{Th}$. Slight variation in the radioactivity content in water of the same type and from the same source can be observed in different locations and even worldwide, mainly due oxidation state of the water, the concentration of suitable complexing agents which can increase the solubility of uranium or thorium.

The annual intakes to the maximum activities measured in all samples are7.7 $\times 10^{3} \mathrm{~Bq} / \mathrm{y}$ for ${ }^{226} \mathrm{Ra}$, and $575 \mathrm{~Bq} / \mathrm{y}$ for ${ }^{228} \mathrm{Ra}$. This result shows that, the measured activities of ${ }^{228} \mathrm{Ra}$ are fifteen times smaller than that recommended by ICRP, and those obtained for ${ }^{226} \mathrm{Ra}$ are more than the maximum contaminant level recommended by ICRP. ${ }^{12}$

\section{Conclusion}

The results have indicated that the average specific activity concentration of ${ }^{226} \mathrm{Ra}$ and ${ }^{228} \mathrm{Ra}$ in the reservoir and spring water in this area, are comparable to those reported in previous works throughout the world. This study has shown that the naturally occurring radionuclides in studied samples differ in quantity from one location to another, and the radionuclide concentrations are a function of the geology of the location. The annual intake by the population of sampling region as a result of ${ }^{226} \mathrm{Ra}$ in this drinking water is estimated to be higher than the maximum limit fixed by ICRP, assuming an individual daily consumption of 2.5 litres a day. There is a need for regular monitoring the radiological quality of the studied drinking water from springs and reservoirs. People can then filter this tap water before consumption, because by filtrating, the radioactive substances that couldn't be dissolved have been eliminated. Following this work, several measures have being taken by the government of Cameroon to ameliorate the quality of drinking water in the country.

\section{Conflict of interest}

The authors declare that they have no conflicts of interest. The authors alone are responsible for the content and writing of the paper.

\section{References}

1. Singh P, Rana NPS, Azam A, et al. Levels of uranium in waters from some Indian cities determined by fission track analysis. Radiation Measurements. 1996; 26:683-7.

2. Marovic G, Sencar J, Franic Z, Lokobauer N. Radium-226 in thermal and mineral springs of Croatia and associated health risks. Journal of Environmental Radioactivity 1996; 33: 309-17.

3. Wrenn ME, Durbin PW, Howard B, et al. Metabolism of ingested $U$ and Ra. Health Phys. 1985; 48:601-33.

4. Olivié-Lauquet G, Allard T, Bertaux J,Muller JP. Crystal chemistry of suspended matter in a tropical hydrosystem, Nyong basin (Cameroon, Africa). ChemGeol. 2000; 170:113-31.

5. Watson JE Jr, Mitsch BF. Ground-water concentrations of 226Ra and 222Rn in North Carolina phosphate lands. Health Phys. 1987;52:361-5.

6. International Atomic Energy Agency. Summary Report on the Post Accident Review Meeting on the Chernobyl Accident. Safety Series 1986; 75-INSAG-1, IAEA.

7. Aarnio PA, Nikkinen MT, Routti JT. SAMPO 90 high resolution interactive gamma-spectrum analysis including automation withmacros. Journal of Radioanalytical and Nuclear Chemistry 1992; 160:286-96.

8. Hakam OK, Choukri A, Reyss JL, Lferde M. Determination and comparison of uranium and radium isotopes activities and activity ratios in samples from some natural water sources in Morocco. J Environ Radioact. 2001;57:175-89.

9. Loomis DP. The relationship between water- system size and 222Rn concentration in North Carolina public water supplies. Health Phys. 1987; 52:69-71.

10. McCurdy DE, Mellor RA. The concentration of 226Ra and 228Ra in domestic and imported bottled waters. Health Phys. 1981;40:250-3.

11. Ahmed NK. Natural radioactivity of ground and drinking water in some areas of upper Egypt. Turkish J EngEnvSci 2004; 28:345-54.

12. International Commission on Radiological Protection. ICRP Pergamon Press Oxford; ICRP Publication 60; Ann. ICRP 21;1991. 